\title{
Crop yields response to water pressures in the Ebro basin in Spain: risk and water policy implications
}

\author{
S. Quiroga ${ }^{1}$, Z. Fernández-Haddad ${ }^{1}$, and A. Iglesias $^{2}$ \\ ${ }^{1}$ Department of Statistics, Economic Structure and International Organization, Universidad de Alcala, Spain \\ ${ }^{2}$ Department of Agricultural Economics and Social Sciences, Universidad Politecnica de Madrid, Spain
}

Received: 1 July 2010 - Published in Hydrol. Earth Syst. Sci. Discuss.: 18 August 2010

Revised: 12 November 2010 - Accepted: 29 December 2010 - Published: 9 February 2011

\begin{abstract}
The increasing pressure on water systems in the Mediterranean enhances existing water conflicts and threatens water supply for agriculture. In this context, one of the main priorities for agricultural research and public policy is the adaptation of crop yields to water pressures. This paper focuses on the evaluation of hydrological risk and water policy implications for food production. Our methodological approach includes four steps. For the first step, we estimate the impacts of rainfall and irrigation water on crop yields. However, this study is not limited to general crop production functions since it also considers the linkages between those economic and biophysical aspects which may have an important effect on crop productivity. We use statistical models of yield response to address how hydrological variables affect the yield of the main Mediterranean crops in the Ebro river basin. In the second step, this study takes into consideration the effects of those interactions and analyzes gross value added sensitivity to crop production changes. We then use Montecarlo simulations to characterize crop yield risk to water variability. Finally we evaluate some policy scenarios with irrigated area adjustments that could cope in a context of increased water scarcity. A substantial decrease in irrigated land, of up to $30 \%$ of total, results in only moderate losses of crop productivity. The response is crop and region specific and may serve to prioritise adaptation strategies.
\end{abstract}

\section{Introduction}

Water conflicts in the Mediterranean have been extensively reported, and many of the studies have analysed the costs for governments to maintain or even increase water supply (Smith, 2002). In the past, studies have focused on the supply

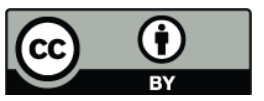

Correspondence to: S. Quiroga

(sonia.quiroga@uah.es) side through cost-benefit analyses. However, with the new water-related problems, such as climate change, droughts and floods, focus on the demand side is needed. For this kind of analysis physical, political and socioeconomic components must be integrated for an optimal management of activities to increase the basin's output. It is crucial for the Mediterranean region, where irrigation represents as much as $90 \%$ of total water consumption (Gómez-Limón and Riesgo, 2004), to measure the risks associated with climate variability in agriculture and to implement water demand policies that promote an efficient allocation and use of resources in the region's farms.

According to the OECD, agriculture is the major user of water in most countries, since about $70 \%$ of total available water is used for irrigation. It also faces the enormous challenge of producing almost $50 \%$ more food by 2030 and doubling production by 2050 . This will likely need to be achieved with less water, mainly because of growing pressures from urbanisation, industrialisation and climate change (OECD, 2010). Agriculture is also the main user of other environmental and natural resources and therefore has an important role to play in global ecosystem sustainability. Therefore, small changes in agricultural water use (in planting, crop management or crop production) can have significant economic and hydrological impacts.

In Spain, irrigated agriculture accounts for $80 \%$ of national consumption of water (Gómez-Limón and Riesgo, 2004) and only $40 \%$ of the land area is suitable for cultivation (Iglesias et al., 2000). This paper focuses on the Ebro basin, where agriculture can reach up to $90 \%$ or more of water consumption. In fact, more than 354245 ha of irrigated land are projected to be added according to the National Irrigation Plan (2001) for the nine regions in the Ebro basin. This represents an increase of $2.110 \mathrm{hm}^{3} / y e a r$ of water demand and an expected increase of $44 \%$ in the irrigated area, raising the total mean to 1128653 hectares. This increase imposes significant additional pressure on aquatic ecosystems and has

Published by Copernicus Publications on behalf of the European Geosciences Union. 
serious environmental implications, such as the maintenance of environmental flows and water quality in rivers. Although some efforts are being made to make the irrigation systems more efficient, trying to reduce water consumption for agriculture, such a huge increase on irrigated land is not likely to occur in a climate change context since more and more severe drought events are expected to happen. In addition, it will be difficult to make this compatible with the water framework directive environmental restrictions. So we have consider three policy scenarios where irrigated area is reduced. The Ebro Basin is located in the Northeast of the Iberian Peninsula with a total area of $85362 \mathrm{~km}^{2}$. This watershed is the largest in Spain, accounting for $17.3 \%$ of the total national area. It is made up of 347 major rivers, including the Ebro River, which drains the basin. It rises in the Cantabrian Mountains and ends in the Mediterranean and has a total length of $910 \mathrm{~km}$ and $12000 \mathrm{~km}$ of main river network (CHEBRO, 2009). The climate in the Ebro basin is primarily Continental Mediterranean, with hot, dry summers, cold, wet winters and short, unstable autumns and springs. In the middle of the basin, the climate is semi-arid and in the northwest corner it is oceanic. Consequently, there is a wide heterogeneity in temperature. In 2007, for example, Tarragona, in the Ebro delta - that is part of the Mediterranean agroclimatic area - reached a maximum temperature of $43^{\circ} \mathrm{C}$, while, Burgos, in the northern Spanish plateau - that is part of the Continental agroclimatic area - got to a minimum of $-22^{\circ} \mathrm{C}$. Our methodological approach deals with these differences since links bio-physical and socio-economic factors.

In this paper, we focus on the evaluation of hydrological risk and water policy implications for agricultural production in the Ebro basin in Spain. We link bio-physical and socioeconomic factors by the introduction of environmental, hydrological, technological, geographical and economic variables to characterize crop yield for the main Mediterranean crops in this basin. The results provide information about the best crop to minimise risk. Later, these models are used to address a simulated policy to assess some policy scenarios with irrigated area adjustments that could cope in a context of increased water shortage. We observe how a reduction in irrigated land results in moderate or significant losses of crop productivity. The response is crop specific and may serve to prioritise adaptation strategies. The article is organized as follows: The second section provides general and detailed information on the methodological steps. The third section describes the results of the estimates crop-water production functions for 8 main crops in the basin. This section shows also the estimates of agricultural added value function, Montecarlo risk analysis and virtual policy scenarios. The final section presents the conclusions of the paper.

\section{Methods}

\subsection{Steps on methodology}

The methodology developed in this study is applied to selected crops in Ebro basin. The methodology developed in this study is applied to selected crops in Ebro basin. Relative to the total agricultural area in the Ebro basin, alfalfa, wheat, grapevine, olive, potato, maize and barley are the seven most representative crops in the Ebro basin since they account for almost $60 \%$ of the total agricultural area in this region. Rice does not represent a large percentage of the total cultivated area in the overall basin, but it is the most important crop in the Ebro delta area and it is an intensively irrigated crop. Alfalfa, maize, potato and rice are mainly irrigated while wheat, barley, grapevine and olive are primarily rainfed crops (Table 4). Models are obtained for each of 8 crops in order to estimate the risk of water variability and policy scenarios.

The methodology includes the following 4 steps: (1) we estimate linear regression models by ordinary least squares (OLS). Statistical models of yield response have proven useful to estimate the water requirements at different locations for selected crops and have also proven useful to evaluate the effects of extreme contingencies and other socioeconomic variables. Extensive literature exists about the estimation of crop production functions to compute the climate effects over crop production (Lobell et al., 2005, 2006; Parry et al., 2004; Iglesias et al., 2000; Hussain and Mudasser, 2007). Some papers focus specifically on the crop-water relationship for irrigated yields (Al-Jamal et al., 2000; Alcalá and Sancho-Portero, 2002; Echevarría, 1998; Acharya and Barbier, 2000). Socio-economic factors have also been included as explanatory variables (Iglesias and Quiroga, 2007; Quiroga and Iglesias, 2009; Griliches, 1964). In this paper, we have linked bio-physical and socio-economic factors introducing environmental, hydrological, technological, geographical and economic variables to characterize crop yield for the main Mediterranean crops in the Ebro river basin. The goal was to analyse economic component (labour and capital) as opposed to the natural component (water for irrigation and irrigated area components of the production function) together. Literature on this specific area includes Acharya and Barbier, 2000; Alcalá and Sancho-Portero, 2002; Echevarría, 1998; and Hussain and Mudasser, 2007. (2) In a second step, we try to understand the interactions between agricultural production and profit functions focusing on water demand. To do so, we analyze the total agricultural gross added value (GAV) of the region and its interaction with the aggregate crop yield. (3) We use the Montecarlo method that it is a simulation technique from which statistical distributions and characterizations can be derived. We apply this method to derive statistical distributions and characterizations of crop yield in response to water patterns or policy adjustments. This method is a powerful and commonly used technique for analyzing complex problems and conducting experiments 


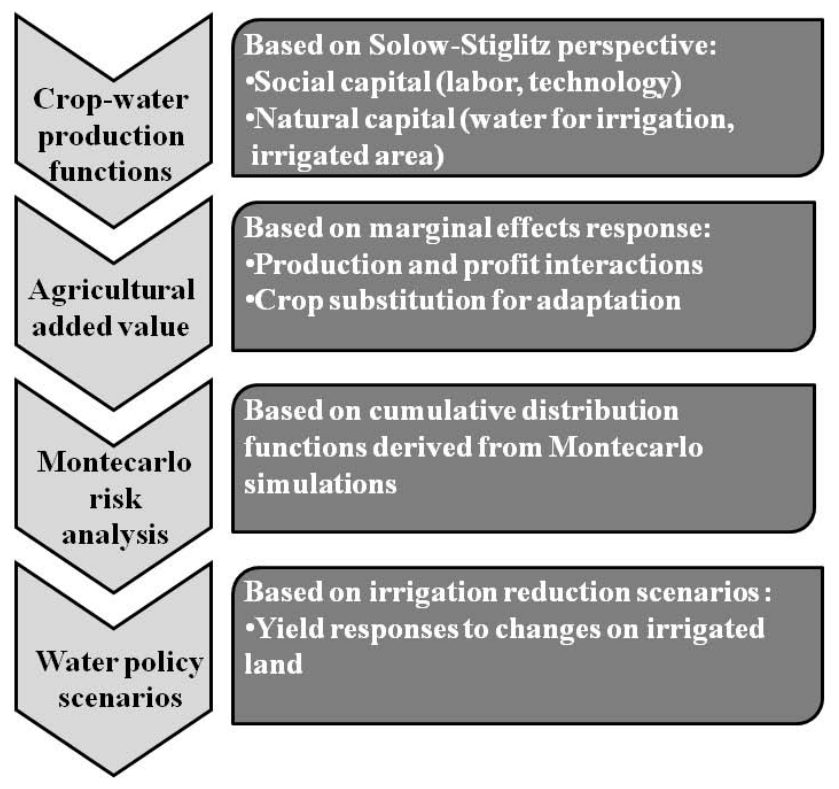

Fig. 1. Steps on methodology.

to evaluate probabilistic risk (Rubinstein, 1981). In agriculture, this method is used to derive statistical distributions and characterizations of crop yield in response to climatic variables and other inputs (Lobell and Ortiz-Monasterio, 2006; Iglesias and Quiroga, 2007). (4) Finally, we simulate the structural adjustments, in this case a decrease in irrigated area (ha) that could allow the agricultural sector, to cope with increased water restrictions for the agricultural sector, see Fig. 1.

In our approach, the estimation of the crop production function plays a fundamental role, since it is then used to evaluate the added value as well as the risk and policy implications. Estimation of production functions is always controversial and each approach has strengths and limitations. Here we have followed the Solow-Stiglitz perspective (Solow, 1974; Stiglitz, 1979, 1997), as specified below. According to Solow (1956), there are two factors of production to obtain output, capital $(K)$ and labour $(L)$. Where its technological possibilities are represented by a production function:

$Y=F(K, L)$

It is assumed that production shows constant returns to scale. Therefore the production function is homogeneous to the first degree. This is equivalent to assuming no scarcity of nonaugmentable resources such as land. If we assume scarceland, this would lead us to decreasing returns to scale in capital and labor and the model would become more Ricardian. Nowadays, it is well known that natural resources are very important to economic growth and environmental sustainability. In this context we find an extended production func- tion named the Solow-Stiglitz model (Solow, 1974; Stiglitz, 1979), which includes natural resources $(R)$.

$Y=K^{\alpha_{1}} L^{\alpha_{3}} R^{\alpha_{2}}$ with $\alpha_{1}+\alpha_{2}+\alpha_{3}=1 \mathrm{y} \alpha_{\mathrm{i}}>0$

Where: $K$ is capital, $L$ is labour, $R$ is natural resources and $\alpha_{1}, \alpha_{2}, \alpha_{3}$ are parameters and represent the elasticity of substitution among the factors. Estimation of production functions is always controversial and each approach has strengths and limitations. In order to put our work in the viewpoint of the productivity literature we used the Solow-Stiglitz perspective. We follow Solow (1956) in the sense that we are modelling a production technology in order to identify productivity change. Some experts have criticized this function because of the assumption that $R$ and $K$ are substitutes, what is not true, since, they are complementary (Daly, 1997). However, nowadays it is extensively used to represent production processes (Stiglitz, 1997). Our approach differs from Solow's initial model from that we use more than two factors of production to obtain output. It is good to say that based in this model we specifically use the usual Cobb-Douglas specification, as it allows a simple estimation and the coefficients obtained have a very intuitive interpretation in terms of elasticities. There are empirical studies that have shown that in agriculture, statistical models of yield response proved to be useful to estimate input requirements at different locations for selected crops (Lobell et al., 2005, 2007; Parry et al., 2004). Limitations of our approach arise from the simplicity of the empirical models and the quality of observed data. The use of statistical models for projections in a different context has been commonly questioned. Nevertheless, regression models are robust within the data range in which they are calibrated. Here, we have used several years of climate data, including a range of temperatures and precipitation extremes, to estimate the models. The data include a range of temperatures and precipitation extremes that vary more than the average changes projected by most of the climate change models, so the limitations in terms to the extent are reduced and the models can be reliably extrapolated since the projections are inside the range in which the regression models apply. In addition, we introduce risk aspects in the evaluation by selecting several geographical locations within each agro-climatic area, several crops and multiple years for the simulations. The result shows cumulative distribution functions to deal with the probabilistic variation.

\subsection{Data}

To characterize our model we use regional, national and international sources of data. Table 1 describes the variables included in this study and the source of data. We have included observed historical data about crop yield, water and climate requirements and socio-economic and geographic characterization of eight representative crops in the 18 regions in the Ebro basin from 1976 to 2002. Crop yield $(Y)$ is defined as the ratio between production $(t)$ and agricultural total area 
Table 1. Percentage of agricultural area for selected crops.

\begin{tabular}{llll|lll|l|l}
\hline \multirow{2}{*}{ Crop } & \multicolumn{2}{l|}{ Percentage of the total agricultural area } & \multicolumn{3}{c|}{ Total cropland (Ha) } & \multicolumn{2}{l}{ Percentage of cropping system } \\
\cline { 2 - 9 } & Rainfed & Irrigation & Total & Rainfed & Irrigation & Total & Rainfed & Irrigation \\
\hline Wheat & 18.97 & 9.55 & 17.00 & 774864 & 102720 & 877584 & 88.30 & 11.70 \\
Barley & 29.90 & 13.04 & 26.38 & 1221483 & 140156 & 1361639 & 89.71 & 10.29 \\
Rice & - & 0.87 & 0.69 & - & 35379 & 35379 & 0.00 & 100.00 \\
Maize & 0.16 & 9.94 & 2.20 & 6700 & 106874 & 113574 & 5.90 & 94.10 \\
Potato & 0.07 & 1.04 & 0.27 & 2868 & 11191 & 14059 & 20.40 & 79.60 \\
Alfalfa & 0.95 & 13.01 & 4.39 & 38758 & 139837 & 179180 & 21.63 & 78.04 \\
Grapevine & 4.36 & 3.72 & 4.22 & 177957 & 39975 & 217932 & 81.66 & 18.34 \\
Olive & 5.13 & 2.64 & 4.61 & 209595 & 28413 & 238008 & 88.06 & 11.94 \\
\hline Total & 59.53 & 53.80 & 59.77 & 2432225 & 604545 & 3037355 & 80.53 & 19.45 \\
\hline
\end{tabular}

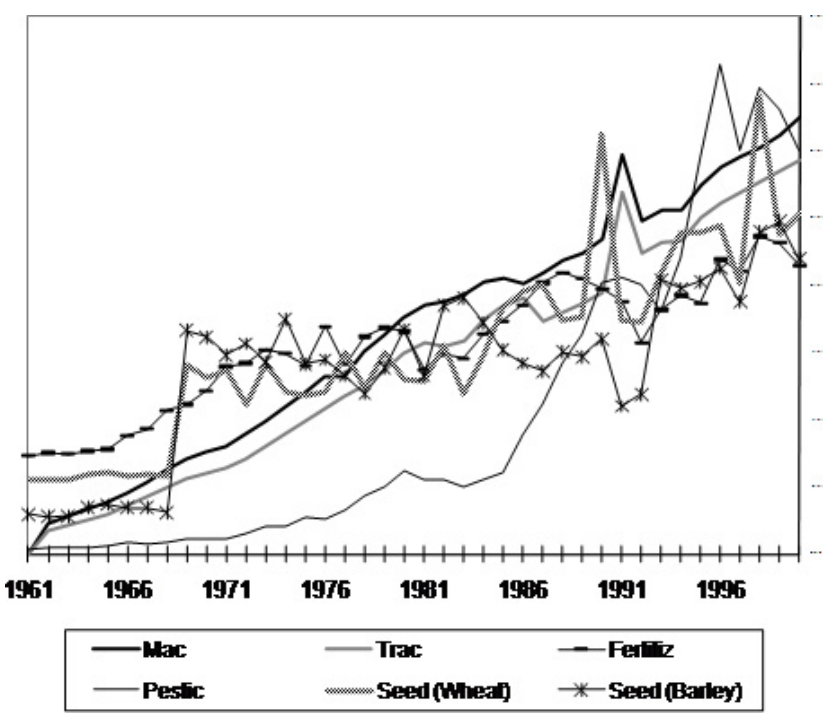

Fig. 2. Evolution of management indicators: farm equipment power (Mac), tractors (Trac), nitrogen fertilizer (Fert), pesticide consumption (Pest), or seeds improvement (Seed). Source: Quiroga, Iglesias, 2010.

(ha) and data were obtained from the Spanish Ministry of Environment (MARM, 2007). Economic and geographic variables were mainly obtained from the Spanish Institute of Statistics (INE, 2009) while technological variables were taken from FAOSTAT (2009) and Food and Agriculture Organization (FAO). To build a proxy variable for irrigation, we used Ebro basin management authority local data, (CHEBRO, 2004) about net water needs of crops. Finally, historical climatic data such as total precipitation, maximum and mean temperatures, and number of days below $0{ }^{\circ} \mathrm{C}$ degrees were taken from the Spanish Meteorological Agency (AEMET) to characterize the impact of climate.

\subsection{Crop-water production function}

We have estimated a crop-water production function that establishes the relationship between crop yield and water applied for a range of crops that represent irrigated agriculture in the Ebro basin. This function is not unique and varies among crops and zones. The specified model is:

$$
\begin{aligned}
& \ln Y_{t}=\alpha \ln Y_{t-1}+\beta_{0}+\beta_{1} L_{t}+\beta_{2} \mathrm{Mac}_{t}+\beta_{3} \mathrm{Mac}_{t-n} \\
& +\beta_{4} \text { Altitude }_{t}+\beta_{5} \text { Area_ebro }_{t}+\beta_{6} \text { Irrig_area }_{t} \\
& +\beta_{7} \text { Irrig }_{t}+\beta_{8} \text { Irrig }_{t}^{2}+\beta_{9} \operatorname{Pr} e c_{i t}+\beta_{10} \mathrm{~T}_{-} \mathrm{Max}_{\mathrm{it}} \\
& +\beta_{11} \mathrm{~T} \mathrm{Max}_{\mathrm{it}}+\beta_{12} \mathrm{Fr}_{\mathrm{it}}+\beta_{13} \mathrm{Dro}_{t}+\varepsilon_{t}
\end{aligned}
$$

Where the dependent variable $\left(\ln Y_{t}\right)$ is the natural logarithm of the crop yield for a site in year $t$. The logarithmic scale for the dependent variable is used in order to homogenize the variance. For strictly positive data, for which a relative scale appears to be natural, taking a log-transformation may be not unimportant (Egozcue et al., 2006). This transformation is widely used, not only for economic variables but also in several areas such as geophysical analyses (Egozcue et al., 2006; Sánchez-Arcilla et al., 2008). The explanatory variables were described on Table 1 . The subscript $i$ on climate and some water variables refers to the three months periods ( $i=\operatorname{def}$ (Dec, Jan, Feb), mam (Mar, Apr, May), jja (Jun, Jul, Aug) and son (Sep, Oct, Nov)).

Agricultural time series are nonstationary since they always present a trend. When variables are nonstationary, normal regression analysis requires a transformation of the data. When there is not enough information about the causes of a such trend, the transformation needed to generate a stationary variable may be attained by simply removing deterministic trends (that is by directly subtracting the trend value from the observations or "detrending"); by taking firstdifferences (that is the variable in year $\mathrm{t}(\mathrm{Yt})$ minus the variable in year $\mathrm{t}-1$ (Yt-1); or by introducing and autoregressive term as a the independent or explanatory variable. (Iglesias and Quiroga, 2007). In our case, we assume that there is 
Table 2. Description of variables.

\begin{tabular}{|c|c|c|c|c|}
\hline $\begin{array}{l}\text { Type of } \\
\text { variable }\end{array}$ & Name & Definition & Unit & Source of Data \\
\hline \multirow[t]{3}{*}{ Economic } & $\mathrm{Y}_{t}$ & Crop yield at a site in year $\mathrm{t}$ & $\mathrm{t} / \mathrm{ha}$ & MARM \\
\hline & $\mathrm{GAV}_{t}$ & $\begin{array}{l}\text { Gross added value of agriculture } \\
\text { a site in year } t\end{array}$ & $\mathrm{~K} €$ current prices & MARM and INE \\
\hline & $\mathrm{L}_{t}$ & $\begin{array}{l}\text { Total employment of agricultural } \\
\text { sector at a site in year } t\end{array}$ & People (thousands) & $\begin{array}{l}\text { Labour Force Survey } \\
\text { (LFS). INE }\end{array}$ \\
\hline \multirow[t]{2}{*}{ Water } & Irrig $_{i t}$ & $\begin{array}{l}\text { Net water needs of crops in } \\
\text { the ith month in year } t\end{array}$ & $\mathrm{~m} / \mathrm{month}$ & $\begin{array}{l}\text { Planning Hydrographic } \\
\text { Office - CHEBRO }\end{array}$ \\
\hline & $\operatorname{Prec}_{i t}$ & $\begin{array}{l}\text { Total precipitation in the ith month/ } \\
3 \text { month period in year } t\end{array}$ & $\mathrm{~mm} / \mathrm{month}$ & AEMET \\
\hline \multirow{2}{*}{ Managment } & $\mathrm{Mac}_{t}$ & Machinery in year $t$ & $\mathrm{~N}^{\circ}$ (thousands) & FAO \\
\hline & $\mathrm{I}_{t}$ & Irrigated area by crop type & ha & MARM \\
\hline \multirow[t]{2}{*}{ Geographic } & Altitude $_{t}$ & $\begin{array}{l}\text { Variables indicating } 0-600, \\
601-1000 \text { and more than } 1000 \mathrm{~m}\end{array}$ & & INE \\
\hline & Area_ebro $t$ & $\begin{array}{l}\text { Dummy variables indicating the } 3 \text { main } \\
\text { areas of the basin: Northern, Central and Low Ebro }\end{array}$ & & Own elaboration \\
\hline \multirow[t]{4}{*}{ Climate } & $\mathrm{T} \_\operatorname{Max}_{i t}$ & $\begin{array}{l}\text { Maximum temperature in the ith month/ } \\
3 \text { month period in year } t\end{array}$ & ${ }^{\circ}$ Celsius & AEMET \\
\hline & $\mathrm{T} \_\mathrm{Mean}_{i t}$ & $\begin{array}{l}\text { Average temperature in the ith month/ } \\
3 \text { month period in year } t\end{array}$ & ${ }^{\circ}$ Celsius & AEMET \\
\hline & $\mathrm{Fr}_{i t}$ & $\begin{array}{l}\text { No. of days with temperatures below } 0{ }^{\circ} \mathrm{C} \\
\text { in the ith month } 3 \text { month period in year } \mathrm{t}\end{array}$ & & AEMET \\
\hline & Dro $_{t}$ & Dummy variable indicating drought years & $\begin{array}{l}1 \text { or } 0 \text { as a function } \\
\text { of SPI critical value }\end{array}$ & $\begin{array}{l}\text { SPI calculated from } \\
\text { AEMET precipitation data }\end{array}$ \\
\hline
\end{tabular}

a causal relationship between yield increase and technological change, and therefore we consider a management variable, the farm equipment power (Mac), to explain yield trend. A range of management indicators such as farm equipment power (Mac), tractors (Trac), nitrogen fertilizer (Fert), pesticide consumption (Pest), or seeds improvement (Seed) have a high correlation (Quiroga and Iglesias, 2010) since they can be considered as a proxy variable for technology and investment in a farm or in the farming sector of a district or country (see Fig. 2).

We used OLS to estimate the coefficients, this is a statistical technique used to compute estimations of parameters and to fit data by generating a line that minimizes the sum of the squared vertical distances from this to the observed responses, in other words, OLS method minimizes the sum of squared residuals. To facilitate the improvement of particular model estimation for each crop, $95 \%$ confidence intervals were estimated assuming normality of the residuals, and significant relations were considered into the estimated model. White's general test (White, 1980) was used to check conditional heteroscedasticity under null hypothesis (Ho) of homoscedasticity or constant variance (Johnston and Dinardo, 2001). Heteroscedasticity exists when the variance of the error term is different for each sample observation. Durbin-Watson statistics are used to check errors autocorrelation existence (Durbin and Watson, 1950). This problem arises when, with time series data, the error terms for different periods are correlated.

When the parameters $\beta_{i}$ are estimated, the marginal effect of a change in the explanatory variables is given by:

$$
\frac{\partial E\left[\ln Y \mid X_{i}\right]}{\partial X_{i}}=\beta_{i}
$$

The signs and magnitude of the marginal effects indicate the effect of a particular input variable $X_{i}$ over the crop yield. In this case, the coefficients of the model have to be interpreted as semi-elasticities because the model presents a semilogarithmic transformation. The interpretation is that semielasticity is responsible for the percent increase of yields produced by a unit change in the input variable.

In the Ebro basin there exists a very high variability in precipitation and it is common to observe that recurrent drought periods affect agricultural production. To date, it is difficult to characterize droughts because of their spatial and temporal properties and the lack of a universally accepted definition (Tsakiris et al., 2007; Hayes, 2004; Keyantash and 
Dracup, 2002; Bradford, 2000). In this work, we use the frequently used Standardized Precipitation Index (SPI, McKee et al., 1993). This index, based on the probability of precipitation for any time scale, calculates the difference in accumulated precipitation between a selected aggregation period and the average precipitation for that same period, it is an index. The calculation of the SPI for any location is based on the long-term precipitation record for a desired time. This long-term record is fitted to a probability distribution, and is then transformed into a normal distribution, implying values that vary around 0 . This allows areas with different climates to be relatively compared (McKee et al., 1993; Steinmann et al., 2005). We have selected 12 months as the aggregated period for calculation. To define the criteria for a drought event we follow McKee et al.'s (1993) table where a drought event occurs when SPI values are -1.0 or less (see Table 2). This criterion was followed in previous detailed works in Spain (Iglesias et al., 2007; Garrote et al., 2007). We, then, construct a dummy variable that equals 1 if the year $t$ is a drought year (with SPI smaller than -1) and 0 in other cases.

Due to the large number of correlated variables the selection of explanatory variables for model specification is important. Greene (2003) shows two alternatives to follow: (a) an inductive approach, which consists in starting with a reduced model and amplifying it by including more variables to a general model. The main problem associated with this approach is that the computed statistics can be biased and inconsistent if the hypothesis is incorrect. (b) A deductive approach, which consists in starting with a given general model to set up a correct fitted model. This approach is frequent in recent analyses since, although inefficient, the estimates and test statistics computed from this over-fitted model are not systematically biased. We therefore, we use the second approach in this paper. As usual the choice of the explanatory variables to include in the final specification follows a deductive approach based on the Akaike (1973) and Schwarz (1978) criteria and adjusted R squared criteria, which are widely used to describe the goodness of model parameterization. A full description of the methods can be found in Greene (2003). To complete this process of variable selection, we observe a strong relationship between some of the explanatory variables which might be a source of collinearity problems. To detect a potential problem in each regression, we calculated the variance inflation factor (VIF) for each of the explanatory variables:

$\operatorname{VIF}\left(x_{k}\right)=\frac{1}{1-R_{k}^{2}}$

VIF represents the squared standard error (or sampling variance) of $\hat{\beta}_{k}$ in the estimated model divided by the squared standard error that would be obtained if $x_{k}$ were uncorrelated with the remaining variables (Chatterjee and Hadi, 2006). So we have a VIF factor for each variable. Then, we follow the following criteria: (i) values larger than 10 give evidence of collinearity and, (ii) a mean of the VIF factor considerably larger than one suggests collinearity. We then proceed to eliminate variables which have a VIF value larger than 10 . The criteria for elimination of variables when collinearity exists have been to eliminate the variable presenting lower impact on the goodness of model. We proceed in an iterative way when collinearity persists.

\subsection{Agricultural added value}

Agricultural added value variations are characterized as a function of crop yields as follows:

$\operatorname{lnGAV}_{t}=\alpha_{0}+\alpha_{i} \ln Y_{i t}+\varepsilon_{t}$

Where the dependent variable $\left(\operatorname{lnGAV}_{t}\right)$ is the natural logarithm of agricultural gross added value for a site in year $t$ and the subscript $i$ refers to the different crops considered and $\alpha_{0}, \alpha_{i}$ are parameters. In this case, the coefficients of the model can be understood as elasticities because the model presents a logarithmic transformation. The interpretation is that elasticity is responsible for the percent increase of yields produced by a one percent increase in the input variable. The coefficients have been estimated by OLS and diagnostic tests were conducted as in the crop-water production function estimation process.

\subsection{Montecarlo risk analysis}

Risk analysis bridges the gap between impact evaluation and policy formulation by focusing policy's interest on consequences (i.e. crop yield) rather than agents (i.e. rainfall or irrigation). There are many definitions of risk but, in a wide sense, risk can be defined as the capacity of a system to suffer losses when it is exposed to an external stressor. In this paper, the probability distribution of production functions for each crop is estimated using the Montecarlo method, which is a key component of uncertainty and probabilistic risk evaluation, since it allows us to generate random samples of statistical distributions to measure risk (Robert and Casella, 2004; Iglesias and Quiroga, 2007; Hammersley and Handscomb, 1975). The approach consists of generating a synthetic series of yield variables using the Monte Carlo method and Latin Hypercube sampling (Just and Weninger, 1999; Atwood et al., 2003).

In agriculture, Montecarlo simulation offers a flexible and accurate approach for investigating and understanding statistical properties of crop yield in response to inputs like irrigation and rainfall (Lobell and Ortiz-Monasterio, 2006). In terms of to water policy, we analyze marginal effects on the statistical model to calculate how a reduction in irrigated area could affect crop yield (Iglesias and Quiroga, 2009; Llop, 2008). Using Montecarlo simulations we obtain 10000 random values of statistical distributions of every crop yield and then analyze the distribution of probabilities to obtain a certain yield (risk level). 
Table 3. SPI Values and drought intensities.

\begin{tabular}{ll}
\hline SPI Values & \\
\hline 2.0 or more & extremely wet \\
1.5 to 1.99 & very wet \\
1.0 to 1.49 & moderately wet \\
-0.99 to 0.99 & near normal \\
-1.0 to -1.49 & moderately dry \\
-1.5 to -1.99 & severely dry \\
-2 and less & extremely dry \\
\hline
\end{tabular}

\subsection{Water policy scenarios}

Under climate change, drought events in the Mediterranean are likely to increase in frequency, duration and intensity and thereby affect crop production in Spain. The understanding of the dynamics of extreme events, including droughts, in future climate scenarios for the Mediterranean is being improved continuously. Although we do not analyse climate change scenarios of runoff, we explore policy implications if runoff is reduced. It is clear that River Basin Management Plans need to be revised to cope with Water Framework Directive (2000), and information about the consequences of changes on water allocation for irrigation and changes on irrigated land is relevant for the decision-making process. In this paper we present information to deal with these alternatives: (i) a risk analysis for changes on water allocation, (ii) theoretical policy scenarios analysis for changes on irrigated land. These policy scenarios are not directly linked to climate change scenarios of runoff. However we present an impact assessment exercise quantifying the implications on agricultural yield of water restrictions, what we think is a necessary first step to discuss possible policies.

We have evaluated three policy scenarios considering a reduction of agricultural irrigated land of $10 \%, 20 \%$ and $30 \%$. These scenarios are consistent with a perspective of increased water scarcity and reflect the policy implications of environmental concerns. The European Water Framework Directive states that it is necessary to restore and conserve the ecological health of rivers, thus the Hydrological Plan of the Ebro Basin must accommodate the irrigated land area, review current concessions and seriously consider the removal of salinised irrigated areas as well as those that consume too many resources due to their low profitability. On the other hand, the establishment of environmental flows in some sections of the Ebro Basin Rivers means that current irrigation areas will have to be reduced. Currently, there is a provisional minimum flow of between $5 \%$ and $10 \%$ of current annual average flow which is made by sections. It is important to observe that the minimum ecological flow in the Ebro river mouth has been set at $100 \mathrm{~m}^{3} \mathrm{seg}^{-1}$. This amount is practically arbitrary, due to the absence of more detailed studies. At this moment, some complementary actions are being taken in order to improve the systems' basin efficiency. For instance, existing or future infrastructure needs to respect the minimum ecological flow required downstream (Herranz, 2008; CHEBRO, 2004).

Also, it is well known that irrigated area is a crucial element when talking about agricultural water demand. In Table 3, we can observe a summary of irrigated areas by Community. These are grouped by large and small irrigation systems for each of the nine Autonomous Communities contained within the basin. According to the CHEBRO, the existing concessional irrigated areas' demand, in the current situation of distribution by crop, is $6310 \mathrm{hm}^{3} \mathrm{yr}^{-1}$ while the current concessional irrigable area is 783948 ha. Here, Aragón and Cataluña account for more than $77 \%$ of this area. It is important to say that this demand does not coincide with the annual supplied volume, which depends on the actually irrigated area, and the actual of annual crops among other factors (CHEBRO normative).

Under a hydrologic-hydraulics point of view and according to the regulation and concessional guidelines' adaptations, the maximum possible irrigation area in the future will reach 985999 ha, corresponding to a demand of $8.213 \mathrm{hm}^{3}$. Under the same assumptions, it would expand to a maximum irrigated area of 1271306 ha with a demand of $9.879 \mathrm{hm}^{3}$. This represents partial increases of $202051 \mathrm{ha}$ and 285307 ha for each of the two horizons. However, the effective development of these areas will depend on agricultural policy decisions taken by competent institutions. Nevertheless, the COAGRET Report (2007) says that the establishment of future environmental flows on some river sections will imply cuts in current irrigation extensions in order to follow the statements of the Water Framework Directive (2000). It is therefore difficult to think about an increase in those ha.

\section{Results}

\subsection{Crop-water production functions and agricultural added value}

The relationship between crop yields and amount of water for irrigation in the six representative crops varies with crop and location (Fig. 3). The relationship between crop yield and irrigation is obviously positive in an initial phase but the marginal decrease to scale. For alfalfa, potato and maize, the most irrigated crops considered, the decreasing phase is not observed within the range of irrigated values considered in this study. For wheat, barley and grapes, optimization of the amount of water is essential. In these crops, additional water beyond a threshold results in reduced output. Rice is not shown since it is always irrigated nor are olives since the amount of irrigated land in this region is relatively small compared to the irrigated land of the other crops. 

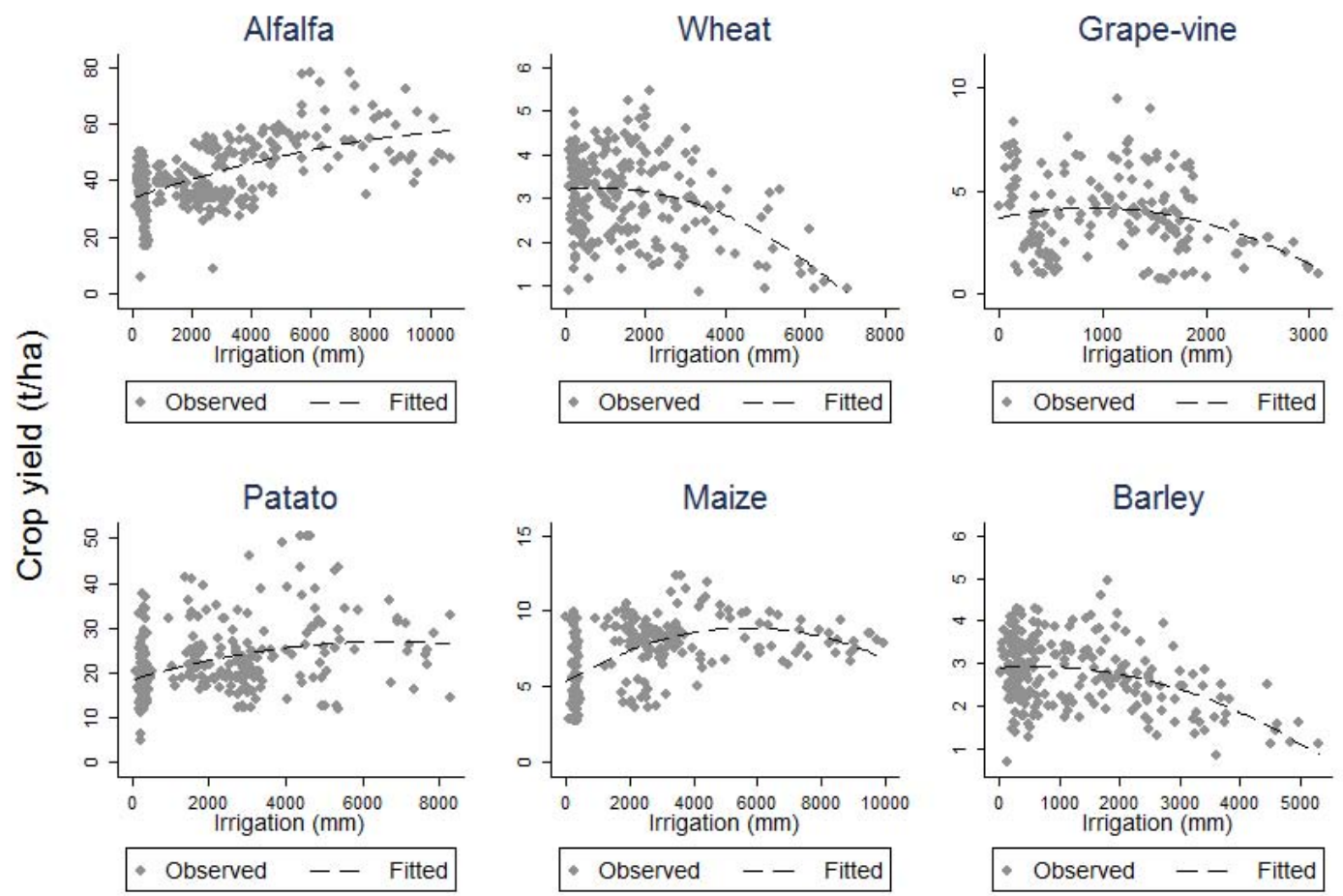

Source: MARM and CHEBRO databases

Fig. 3. Observed crop response to irrigation water applied.

Table 4. Irrigated area by irrigation systems.

\begin{tabular}{l|ll|ll|ll}
\hline \multirow{2}{*}{ Region } & \multicolumn{5}{c}{ Irrigation Area and Porcentages } \\
\cline { 2 - 7 } & \multicolumn{2}{|c}{ Large systems } & \multicolumn{2}{|c}{ Small systems } & \multicolumn{2}{c}{ Total } \\
\cline { 2 - 7 } & ha & $\%$ & ha & $\%$ & ha & $\%$ \\
\hline Aragón & 237813 & 52.2 & 161721 & 49.1 & 399045 & 50.9 \\
Cantabria & 0 & 0.0 & 553 & 0.2 & 553 & 0.1 \\
Cataluña & 160625 & 35.3 & 46316 & 14.1 & 207036 & 26.4 \\
Castilla - La Mancha & 0 & 0.0 & 241 & 0.1 & 241 & 0.0 \\
La rioja & 17584 & 3.9 & 34864 & 10.6 & 52448 & 6.7 \\
Castilla - León & 0 & 0.0 & 8.913 & 2.7 & 8.913 & 1.1 \\
Navarra & 39359 & 8.6 & 48407 & 14.7 & 87766 & 11.2 \\
Valencia & 0 & 0.0 & 275 & 0.1 & 275 & 0.0 \\
País Vasco & 0 & 0.0 & 27277 & 8.3 & 27277 & 3.5 \\
\hline Total land area & 455381 & 100.0 & 328568 & 100.0 & 783948.69 & 100.0 \\
\hline
\end{tabular}

Irrigated land has evolved differently for each crop and area considered (Fig. 4). In the upper basin (Burgos province) the proportion of irrigated area for the cereals crops increases during the period of analysis. This increase is a result of the lack of water scarcity problems in this part of the basin during the period of analysis. In contrast, in the middle basin (Zaragoza province) and the lower basin (Tarragona province) the trend is clearly downward, except in the case of maize in Zaragoza, where the tendency is almost constant. This reflects an increased limitation of irrigation due to prioritization of water for the environment.

We estimated crop-water production functions that explain the influence of water on crop productivity and also incorporate a wide range of variables (Table 5). The increasing trend in crop productivity is explained largely by technological and management variables. We assume that yield 

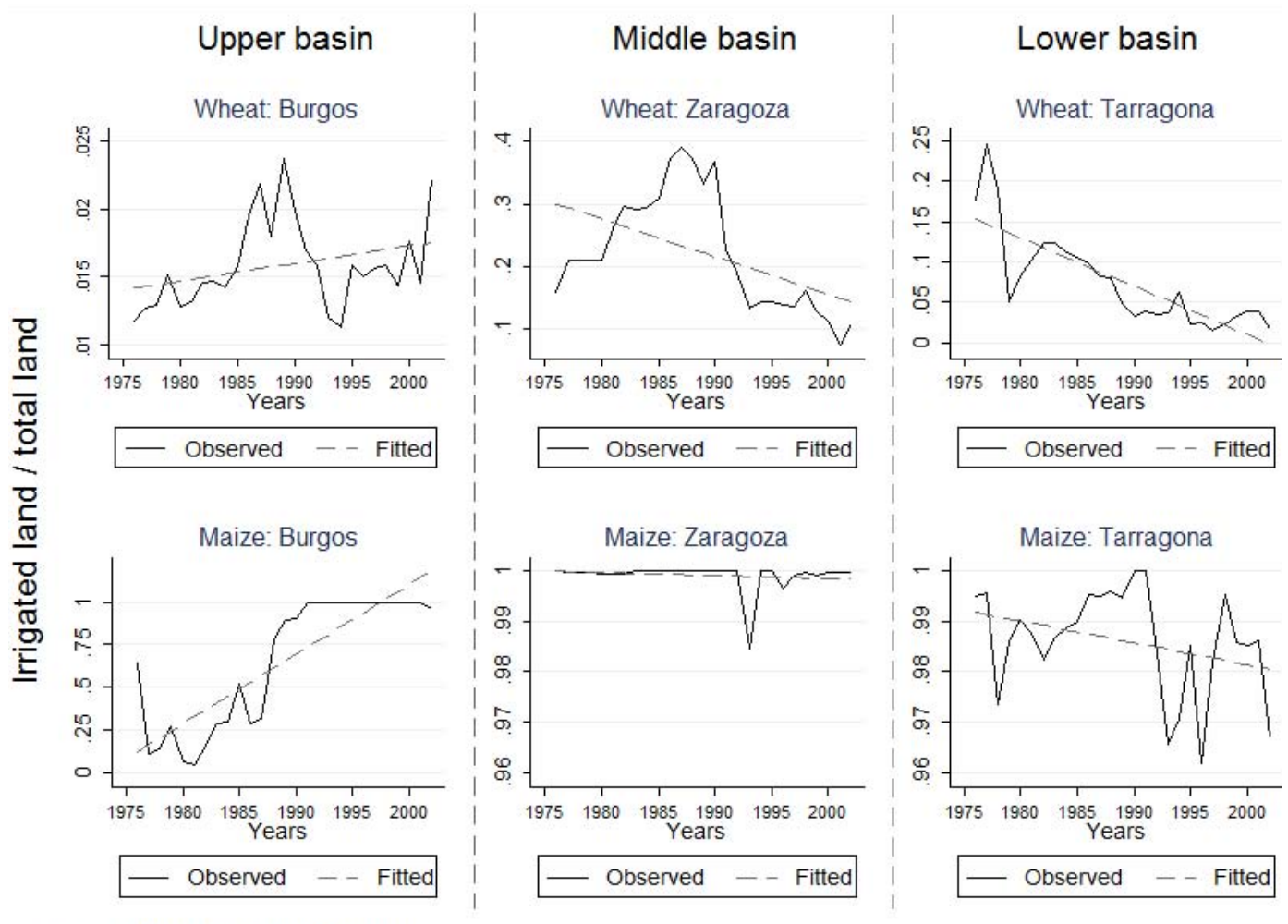

Source: MARM and CHEBRO databases

Fig. 4. Irrigated land for wheat and maize at representative areas of Upper (Northern, Central and Low Ebro: Burgos, Zaragoza and Tarragona.

increases due to improved varieties are linked to more intensified management. We tested the adequacy of the functions to represent crop-water production functions as outlined in the methods section; in the cases where regressions present heteroskedasticity the regressions are estimated with the White method (1980) to obtain robust estimates (following Wooldridge, 2003).

In general the eight crop-water production functions present the expected signs according to the agricultural processes. Irrigation for alfalfa, wheat, rice, potato, maize and barley present a positive impact on the crop yield but this decreases after a given amount of water. Irrigation is not statistically significant for grapevine and olive yield. This may be due to the small area of these crops under irrigation and to the fact that irrigation in these crops is "deficit irrigation" used only to maintain yield during drought periods. Irrigation area also has an important impact on alfalfa, wheat, grapevine, potato, maize and olive. For this last crop, the effect of irrigation area is the largest. In contrast, drought does not show significant impacts for all crops. Only wheat, barley, and grapevine have negative significant impacts in this variable probably because these crops are rainfed. In other words, except for olives, irrigated crops do not show evidence of significant impact of drought on their yield. The quantity of machineries has a positive effect after one period
$(\operatorname{Mac}(-1))$ or even two periods $(\operatorname{Mac}(-2))$. That can respond to a lag in the investments on machinery. In the case of agricultural labour, the variable is at macro level and the negative effect is responding to the decreasing returns to scale when additional labour force move to agricultural sector.

Table 6 shows the estimated profit function for each crop yield. The estimation of this function has been considered for all crops; however, we only took into account those that are significant. In other words the effects may be poorly specified for crops that are not represented in the entire geographic area. We note that when yields of alfalfa, maize, potatoes and wheat increase by 1 unit, the agricultural gross added value increases.

A strictly economic analysis might suggest the desirability of a stronger orientation of production towards wheat and maize, because an increase in the yield of these crops has a major impact on the region's agricultural GAV. However, this does not take into account the cost of virtual water. Even though today the Ebro Delta does not present problems of availability of water the problems associated with the necessity of large amounts of irrigation water that are caused due to factors such as the crop's characteristics, natural ground permeability and capillary rise of salt water should not be ignored. Therefore, an analysis of water risk management is necessary. In the next section, we analyze the water risk 
Table 5. Estimated coefficients of crop-water functions, robust t-statistics and $R^{2}$.

\begin{tabular}{|c|c|c|c|c|c|c|c|c|}
\hline & Alfalfa & Wheat & Rice & Grapevine & Olive & Potato & Maize & Barley \\
\hline $\operatorname{Ln}\left(\mathrm{Y}_{t-1}\right)$ & & & & $\begin{array}{l}0.4441 \\
{[4.73]^{* * *}}\end{array}$ & & & & \\
\hline $\mathrm{L}$ & & & & & & & $\begin{array}{l}-0.0116 \\
{[3.66] * * *}\end{array}$ & $\begin{array}{l}-0.0118 \\
{[3.66]^{* * *}}\end{array}$ \\
\hline Mac & $\begin{array}{l}-0.0067 \\
{[2.05]^{* *}}\end{array}$ & $\begin{array}{l}-0.0103 \\
{[3.19]^{* * *}}\end{array}$ & & & $\begin{array}{l}0.0022 \\
{[4.74] * * *}\end{array}$ & $\begin{array}{l}0.0013 \\
{[9.62]^{* * *}}\end{array}$ & $\begin{array}{l}0.0010 \\
{[5.61]^{* * *}}\end{array}$ & $\begin{array}{l}0.0007 \\
{[3.25]^{* * *}}\end{array}$ \\
\hline $\mathrm{Mac}_{t-1}$ & $\begin{array}{l}0.0069 \\
{[2.16]^{* *}}\end{array}$ & $\begin{array}{l}0.0109 \\
{[3.39]^{* * *}}\end{array}$ & & $\begin{array}{l}0.0010 \\
{[3.39]^{* * *}}\end{array}$ & & & & \\
\hline $\mathrm{Mac}_{t-2}$ & & & $\begin{array}{l}0.0005 \\
{[1.73]^{*}}\end{array}$ & & & & & \\
\hline Altitude $_{(0-600)}$ & & $\begin{array}{l}-4.80 \mathrm{E}-05 \\
{[4.24]^{* * *}}\end{array}$ & & $\begin{array}{l}-6.20 \mathrm{E}-05 \\
{[4.41]^{* * *}}\end{array}$ & & & & \\
\hline Altitude $_{(601-1000)}$ & $\begin{array}{l}-2.06 \mathrm{E}-05 \\
{[4.05]^{* * *}}\end{array}$ & $\begin{array}{l}2.58 \mathrm{E}-05 \\
{[1.69]^{*}}\end{array}$ & & & & & & $\begin{array}{l}2.66 \mathrm{E}-05 \\
{[1.86]^{*}}\end{array}$ \\
\hline Altitude $_{(+1000)}$ & $\begin{array}{l}-1.49 \mathrm{E}-05 \\
{[3.36]^{* * *}}\end{array}$ & $\begin{array}{l}-8.94 \mathrm{E}-05 \\
{[6.54]^{* * *}}\end{array}$ & & $\begin{array}{l}-6.57 \mathrm{E}-05 \\
{[4.01]^{* * *}}\end{array}$ & & & $\begin{array}{l}-1.38 \mathrm{E}-05 \\
{[2.16]^{* *}}\end{array}$ & $\begin{array}{l}-6.53 \mathrm{E}-05 \\
{[4.89]^{* * *}}\end{array}$ \\
\hline Cent_ebro & $\begin{array}{l}-0.0412 \\
{[1.28]}\end{array}$ & $\begin{array}{l}-0.1006 \\
{[1.69]^{*}}\end{array}$ & & $\begin{array}{l}-0.0781 \\
{[1.56]}\end{array}$ & & & $\begin{array}{l}-0.2954 \\
{[6.32] * * *}\end{array}$ & $\begin{array}{l}-0.2646 \\
{[4.15]^{* * *}}\end{array}$ \\
\hline Northern_ebro & $\begin{array}{l}0.2226 \\
{[4.53]^{* * *}}\end{array}$ & $\begin{array}{l}-0.4780 \\
{[2.97]^{* * *}}\end{array}$ & & $\begin{array}{l}-0.3589 \\
{[3.08]^{* * *}}\end{array}$ & & & $\begin{array}{l}-0.3249 \\
{[5.22] * * *}\end{array}$ & $\begin{array}{l}-0.6043 \\
{[4.07]^{* * *}}\end{array}$ \\
\hline Irrig_area & $\begin{array}{l}0.8531 \\
{[9.65]^{* * *}}\end{array}$ & $\begin{array}{l}0.5964 \\
{[3.75]^{* * *}}\end{array}$ & & $\begin{array}{l}0.9993 \\
{[4.53]^{* * *}}\end{array}$ & $\begin{array}{l}1.6479 \\
{[4.22] * * *}\end{array}$ & $\begin{array}{l}0.5693 \\
{[11.41]^{* * *}}\end{array}$ & $\begin{array}{l}0.7691 \\
{[9.00]^{* * *}}\end{array}$ & \\
\hline Irrig & $\begin{array}{l}0.0963 \\
{[7.10]^{* * *}}\end{array}$ & $\begin{array}{l}0.2024 \\
{[4.73]^{* * *}}\end{array}$ & $\begin{array}{l}0.1543 \\
{[2.08]^{* *}}\end{array}$ & & & $\begin{array}{l}0.0355 \\
{[2.08]^{* *}}\end{array}$ & $\begin{array}{l}0.0766 \\
{[3.35] * * *}\end{array}$ & $\begin{array}{l}0.2496 \\
{[5.19]^{* * *}}\end{array}$ \\
\hline Irrig $^{\wedge} 2$ & $\begin{array}{l}-0.0083 \\
{[5.69]^{* * *}}\end{array}$ & $\begin{array}{l}-0.0447 \\
{[6.59]^{* * *}}\end{array}$ & $\begin{array}{l}-0.0213 \\
{[1.89]^{*}}\end{array}$ & & & $\begin{array}{l}-0.0002 \\
{[0.08]}\end{array}$ & $\begin{array}{l}-0.0027 \\
{[1.38]^{*}}\end{array}$ & $\begin{array}{l}-0.0649 \\
{[6.24]^{* * *}}\end{array}$ \\
\hline Prec $_{\text {def }}$ & & & & & $\begin{array}{l}0.0015 \\
{[2.41]^{* *}}\end{array}$ & & $\begin{array}{l}0.0006 \\
{[3.49]^{* * *}}\end{array}$ & \\
\hline Prec $_{\text {mam }}$ & $\begin{array}{l}0.0010 \\
{[6.52]^{* * *}}\end{array}$ & & & & & & & \\
\hline $\operatorname{Prec}_{\mathrm{jja}}$ & & & & & $\begin{array}{l}0.0017 \\
{[2.58]^{* *}}\end{array}$ & & $\begin{array}{l}0.0006 \\
{[2.88]^{* * * *}}\end{array}$ & \\
\hline Prec $_{\text {son }}$ & & $\begin{array}{l}0.0005 \\
{[3.30]^{* * *}}\end{array}$ & & & & & $\begin{array}{l}0.0000 \\
{[0.20]}\end{array}$ & $\begin{array}{l}0.0004 \\
{[2.33]^{* *}}\end{array}$ \\
\hline Prec $_{\text {year }}$ & & & & & & $\begin{array}{l}0.0001 \\
{[1.80]^{*}}\end{array}$ & & \\
\hline$T_{-} M_{a x}$ def & & & & & & & $\begin{array}{l}0.0059 \\
{[2.17]^{* *}}\end{array}$ & \\
\hline T_Maxmam & & $\begin{array}{l}-0.0098 \\
{[3.39]^{* * *}}\end{array}$ & & & & & & $\begin{array}{l}-0.0133 \\
{[4.33]^{* * *}}\end{array}$ \\
\hline $\mathrm{T}_{-} \mathrm{Max}_{\mathrm{jja}}$ & & & & $\begin{array}{l}-0.0099 \\
{[3.10]^{* * *}}\end{array}$ & $\begin{array}{l}-0.0273 \\
{[3.34]^{* * *}}\end{array}$ & & & \\
\hline T_Max $_{\text {son }}$ & & $\begin{array}{l}0.0092 \\
{[2.35]^{* *}}\end{array}$ & & & & & $\begin{array}{l}0.0069 \\
{[1.88]^{*}}\end{array}$ & $\begin{array}{l}0.0187 \\
{[5.03]^{* * *}}\end{array}$ \\
\hline T_Mean year & $\begin{array}{l}0.0474 \\
{[4.12]^{* * *}}\end{array}$ & $\begin{array}{l}-0.0879 \\
{[3.00]^{* * *}}\end{array}$ & $\begin{array}{l}0.0377 \\
{[2.24]^{* *}}\end{array}$ & & & $\begin{array}{l}-0.0685 \\
{[10.02]^{* * *}}\end{array}$ & $\begin{array}{l}-0.0602 \\
{[2.95]^{* * *}}\end{array}$ & $\begin{array}{l}-0.1394 \\
{[5.40]^{* * *}}\end{array}$ \\
\hline $\mathrm{Fr}_{\mathrm{def}}$ & & $\begin{array}{l}-0.0022 \\
{[1.67]^{*}}\end{array}$ & & & & & & $\begin{array}{l}-0.0019 \\
{[1.41]}\end{array}$ \\
\hline $\mathrm{Fr}_{\mathrm{mam}}$ & & $\begin{array}{l}-0.0090 \\
{[1.66]^{*}}\end{array}$ & & & $\begin{array}{l}-0.0297 \\
{[2.80]^{* * *}}\end{array}$ & & & $\begin{array}{l}-0.0117 \\
{[2.53]^{* *}}\end{array}$ \\
\hline $\mathrm{Fr}_{\text {son }}$ & & & & & $\begin{array}{l}0.0303 \\
{[2.79]^{* * * *}}\end{array}$ & $\begin{array}{l}-0.0120 \\
{[4.06]^{* * *}}\end{array}$ & $\begin{array}{l}-0.0069 \\
{[2.11]^{* *}}\end{array}$ & \\
\hline Dro & & $\begin{array}{l}-0.1281 \\
{[2.22]^{* *}}\end{array}$ & & $\begin{array}{l}-0.1328 \\
{[1.97]^{*}}\end{array}$ & & & & $\begin{array}{l}-0.1737 \\
{[3.75]^{* * *}}\end{array}$ \\
\hline Constant & $\begin{array}{l}2.3298 \\
{[13.36]^{* * *}}\end{array}$ & $\begin{array}{l}2.4157 \\
{[5.08]^{* * *}}\end{array}$ & $\begin{array}{l}0.5408 \\
{[1.60]}\end{array}$ & $\begin{array}{l}1.4124 \\
{[4.13]^{* * *}}\end{array}$ & $\begin{array}{l}0.3029 \\
{[0.36]}\end{array}$ & $\begin{array}{l}2.5529 \\
{[15.34]^{* * *}}\end{array}$ & $\begin{array}{l}0.6545 \\
{[1.83]^{*}}\end{array}$ & $\begin{array}{l}2.4135 \\
{[5.05]^{* * *}}\end{array}$ \\
\hline $\begin{array}{l}\text { Adj R-squared } \\
\text { White test: } p \text {-value }\end{array}$ & $\begin{array}{l}0.65 \\
0.0008\end{array}$ & $\begin{array}{l}0.63 \\
0.4362\end{array}$ & $\begin{array}{l}0.17 \\
0.3695\end{array}$ & $\begin{array}{l}0.84 \\
0.0380\end{array}$ & $\begin{array}{l}0.41 \\
0.6504\end{array}$ & $\begin{array}{l}0.62 \\
0.0000\end{array}$ & $\begin{array}{l}0.77 \\
0.0154\end{array}$ & $\begin{array}{l}0.55 \\
0.5003\end{array}$ \\
\hline
\end{tabular}

$\mathrm{t}$ statistics and robust t statistics in brackets, ${ }^{*}$ significant at $10 \% ;{ }^{* *}$ significant at $5 \%$; ${ }^{* * *}$ significant at $1 \%$ 
Table 6. Estimated coefficients of profit function (logarithm of the gross added value), robust t-statistics [in brakets] and $R^{2}$.

\begin{tabular}{ll}
\hline & Coefficients \\
\hline Yield_Alfalfa & $\begin{array}{l}0.04 \\
{[4.58]^{* * *}}\end{array}$ \\
\hline Yield_Maize & $\begin{array}{l}0.11 \\
{[3.56]^{* * *}}\end{array}$ \\
\hline Yield_Potato & 0.02 \\
& {$[2.49]^{* *}$} \\
\hline Yield_Wheat & 0.20 \\
& {$[2.80]^{* * *}$} \\
\hline Constant & 9.31 \\
& {$[22.08]^{* * * *}$} \\
\hline Observations & 133 \\
R-squared & 0.31 \\
\hline
\end{tabular}

Robust $\mathrm{t}$ statistics in brackets ${ }^{*}$ significant at $10 \% ;{ }^{* *}$ significant at $5 \% ;{ }^{* * *}$ significant at $1 \%$

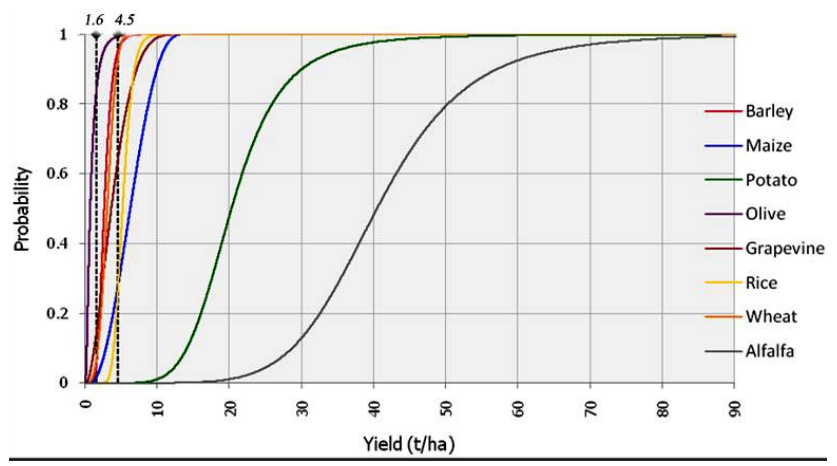

Fig. 5. Cummulative density probability function of crop yield.

of the selected crops and the impacts of potential changes in water policy. It is important to note that the contribution to the gross added value includes direct payments linked to crop productivity during the period of analysis (before 1986 from the agricultural policy in Spain and since 1986 from the EU Common Agricultural Policy). The recent decupling of productivity and payments, since 2008, may change the relative contribution of each crop to the gross added value.

\subsection{Montecarlo risk analysis}

Statistical properties of crop yield in response to water patterns were derived using Montecarlo simulations in order to asses risk levels. Figure 5 shows the cumulative density probability functions where significant differences in risk levels between crops can be observed. According to these cumulative distribution functions, the probability of having low yields is higher for olive, barley and wheat and lower for alfalfa and potato.

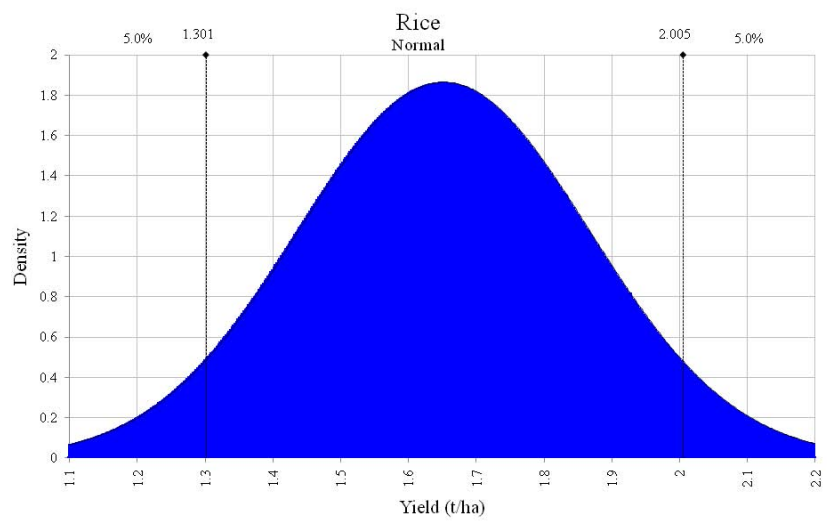

Fig. 6. Distribution function of simulated rice yield in the low Ebro. Normal distribution with mean $=1.62$ and $\mathrm{SD}=0.21$.

Table 7 provides the detailed statistical properties from Fig. 5. Rice and alfalfa present a low variation coefficient (CV) while olive and grapevine have a high variability. On the other hand, we observed that the skewness coefficient is above +1 in potato, olive, alfalfa and barley, indicating that they have an elevated probability of obtaining results above the mean. Also, the skewness coefficient is greater than 0 , indicating that there is no large probability of having a low yield. The kurtosis coefficient for every crop yield is lower than 3, and we have a platykurtic distribution that indicates that the probability distribution functions of the crop yields have a wide peak (a lower probability than a normally distributed variable of values near the mean) and thin tails (a lower probability than a normally distributed variable of extreme values). Figure 6, presents the distribution function for rice, which is practically normal.

\subsection{Water policy scenarios}

Although irrigation contributes to social welfare in many regions, it cannot be rural development's the sole concern. As we mentioned before, nowadays there are no explicit restrictions on the irrigation area in the Ebro basin. However, within the context of increases of water demands and policy developments such as the Water Framework Directive restrictions context, it is necessary that the Basin Plan consider adaptation measures such as changes in irrigated land to cope with environmental and sustainability constraints. Thus, we propose three possible scenarios, in which we assume a reduction of the irrigated area by $10 \%, 20 \%$ and $30 \%$. Table 8 shows the yield changes responding to these scenarios.

A substantial decrease in irrigated land, of up to $30 \%$ of total, results in only moderate losses of crop productivity. The response is crop specific, wheat is the least affected and alfalfa is the most affected. These results contrast with the relative importance of the crop as measured by the gross added value (Table 6). Both indicators, the gross added value and the changes in crop productivity, are useful to choose 
Table 7. Statistical properties of yield simulations.

\begin{tabular}{lllllllll}
\hline & Alfalfa & Wheat & Rice & Grapevine & Olive & Potato & Maize & Barley \\
\hline Mean & 42.149 & 3.092 & 5.343 & 3.973 & 0.970 & 21.602 & 6.352 & 2.814 \\
Median & 40.472 & 3.083 & 5.222 & 3.555 & 0.744 & 20.293 & 6.184 & 2.671 \\
SD & 12.565 & 0.995 & 1.157 & 2.300 & 0.781 & 7.705 & 2.648 & 0.933 \\
CV & 29.810 & 32.196 & 21.661 & 57.893 & 80.457 & 35.668 & 41.692 & 33.171 \\
Maximun & 183.797 & 7.150 & 13.232 & 11.513 & 7.307 & 162.001 & 13.075 & 9.475 \\
Minimum & 8.909 & 0.175 & 2.188 & 0.167 & 0.039 & 4.661 & 0.542 & 0.777 \\
Skewness & 1.547 & 0.088 & 0.668 & 0.678 & 1.843 & 2.984 & 0.216 & 1.029 \\
Kurtosis & 9.759 & 2.736 & 3.859 & 2.771 & 7.786 & 28.900 & 2.246 & 4.908 \\
\hline
\end{tabular}

Table 8. Yield changes for irrigated area policy scenarios.

\begin{tabular}{lcccccc}
\hline \multirow{2}{*}{$\begin{array}{l}\text { Decrease in } \\
\text { irrigated land }\end{array}$} & Alfalfa & Wheat & Grapevine & Olives & Potatoes & Maize \\
\hline$-10 \%$ & -4.8 & -0.7 & -1.5 & -2.2 & -4.3 & -4.8 \\
$-20 \%$ & -11.2 & -1.4 & -2.9 & -4.4 & -8.4 & -9.4 \\
$-30 \%$ & -15.5 & -2.0 & -4.3 & -6.6 & -12.3 & -13.7 \\
\hline
\end{tabular}

Yield decrease

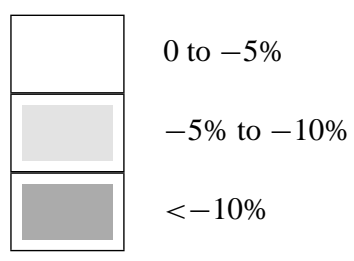

adaptation strategies. For example, the contribution of maize to the gross added value is large and the yield is highly reduced as result of irrigated land reduction. Therefore the economic losses of irrigated land reduction in a maize producing area are significant. In contrast, although the yield reduction of alfalfa is comparable to that of maize, the resulting economic loss due to limitation in irrigated land is smaller because alfalfa's contribution to the gross added value is low.

The reductions are consistent given the uncertainty of future policy and our purpose is to show the implications in terms of production risk. Uncertainties of the analysis derive from the imperfect data (e.g., representative climate stations), limitation of the models to represent complex reality (statistical models of yield response are a simplification of the climate, agricultural, and social effects on crop yield), and the assumptions about the future (policy scenarios). Using the models presented in Table 8 , we note that these scenarios imply yield losses, ranging from $1 \%$ to more than $15 \%$. Regardless of the extent of the reduction in irrigated land imposed by the policy, we see that wheat and grapevine do not suffer major losses in yield performance, whereas alfalfa, potato and maize would be affected considerably given that they are mostly irrigated crops. Since the irrigation area was not significant for rice (which is $100 \%$ irrigated), we cannot observe, using this technique, the amount of decrease in its yield would most likely decline. One important factor to consider is the fact that the losses are not proportional. Therefore, the loss is larger when the irrigation area is reduced from $10 \%-20 \%$ scenarios than when it is reduced from $20 \%-$ $30 \%$ scenario. Finally, the reductions in crop yields can be used to estimate the necessary incentives for the implementation of environmental goals (Iglesias and Quiroga, 2009).

\section{Conclusions}

Water scarcity in the Mediterranean is highly to increase as consequence of climate change and therefore this will emphasize pressures on food production. This paper presents an analysis of the factors that affect eight major crops in the Ebro river basin including latent risks as well as policies that could be implemented. We analyzed the marginal effects on 
the statistical model to calculate the effect of a potential reduction in irrigated area on crop yield. This study was based on an analysis of demand.

Extended water production functions by crop were estimated. These show the expected signs for most of the variables. Focusing on the hydrological variables, our results show that an increase in irrigation and in the irrigated area has a positive impact on crop yields. However, the impact of irrigation is not always positive given that after a certain quantity of water supplied to the crop, yield begins to decrease (negative sign in irrigation elevated to square). The precipitation also shows a positive impact on crop yields, except for maize in the son quarter (Sep, Oct, Nov), which might be due to excessive water from irrigation, given the usual humidity of this time of the year. A strictly economic analysis might suggest that production could be oriented to wheat and maize, given their impact on agricultural gross value added of the area. However, this does not consider the cost of virtual water. Maize is a major crop in the Ebro Delta, in the low basin, that could suffer a reduction on water availability. An analysis of water risk management is needed. Rice and potatoes show a low variation coefficient, implying low variability. Olive shows low yield and high variability in this area, although under a reduction in irrigated area scenario, this crop is not severely affected. Potato, maize and alfalfa are the ones most affected by a reduction in irrigated area, because they are mainly irrigated crops.

We present crop responses to different policy scenarios of reductions on irrigated area. In a climate change context, more and more severe drought events are expected to happen in the Ebro basin. This could lead to the river basin management authority to reduce water availability. Although the national irrigation plan consider increases in irrigated land and some efforts are being made to make the irrigation systems more efficient, trying to reduce water consumption for agriculture, such an increase won't be likely to occur. Instead of this, we have considered the consequences for crop production of three policy scenarios where irrigated area is reduced. We quantify the implications on crop productivity and agricultural value added. To assess optimal water management among different crops it is necessary to know the priorities of policy-makers, since the large loss of production is not the main economic loss. Some crops are linked to rural landscapes or customs that sometimes is important to maintain, water demand is different for each crop and also economic revenues, so there is not a unique crop mix that minimize losses, since the definition of loss depends on the objectives. A multicriteria analysis can be performed in a further step, but it has not been addressed here. Finally, the methodology presented here can be extended to examine additional factors that affect crop yield and interact with water demand, such as climate change, irrigation systems, and fertilizer application.
Acknowledgements. This research has been supported by the European Commission CIRCE project and the ARCO project of the Spanish Ministry of Environment, Rural, and Marine Affairs (MARM). We also acknowledge the data support of Agencia Estatal de Meteorología (AEMET) and CEIGRAM for the support for the publication.

Edited by: A. Cancelliere

\section{References}

Acharya, G. and Barbier, E. B.: Valuing groundwater recharge through agricultural production in the Hadejia-Nguru wetlands in northern Nigeria, Agr. Econ., 22, 247-259, 2000.

Akaike, H.: A maximum likelihood estimation of Gaussian autoregressive moving average models, Biometrika, 60, 255-265, 1973.

Alcalá, F. and Sancho-Portero, I.: Agua y producción agrícola: un análisis econométrico del caso de Murcia, Estudios Agrosociales y Pesqueros, 197, 129-157, 2002.

Al-Jamal, M. S., Sammis, T. W., and Ball, S. D.: Computing the crop water production function for onion, Agr. Water Manage., 46, 29-41, 2000.

Atwood, J., Shaik, S., and Watts, M.: Are crop yields normally distributed? A re-examination, Am. J. Agr. Econ., 85, 888-901, 2003.

Bradford, R. B.: Drought events in Europe, in: Drought and drought mitigation in Europe, edited by: Vogt, J. V. and Somma, F., Kluwer Academic Drodrecht, 7-20, 2000.

Chatterjee, S. and Hadi, A. S.: Regression Analysis by Example, 4th Edition, Wiley, New York, USA, 236-239, 2006.

CHEBRO: Revisión de las Necesidades Hídricas Netas de los Cultivos en la Cuenca del Ebro, 1961-2002, Confederación Hidrográfica del Ebro, Zaragoza, Spain, 2004.

CHEBRO (Confederación Hidrográfica del Ebro): http: //www.chebro.es/contenido.visualizar.do?idContenido= 2133\&idMenu=2001, Zaragoza, Spain, 2009.

COAGRET: Criterios sobre las líneas de demandas futuras de agua 2008-2025 en la Cuenca Hidrográfica del Ebro Esquema De Temas Importantes: Plan Hidrológico 2007, Association of people affected by big reservoirs report, 2007.

Durbin, J. and Watson, G. S.: Testing for Serial Correlation in Least Squares Regression, I. Biometrika, 37, 409-428, 1950.

Echevarría, C.: A three-factor agricultural production function: the case of Canada, International Economic Journal, 12(3), 63-75, 1998.

FAOSTAT: Resources (Machinery), Years: 1961-2007, Food and Agriculture Organization of the United Nations (FAO), 2009.

Garrote, L., Flores, F., and Iglesias, A.: Linking drought indicators to policy: The case of the Tagus basin drought plan, Water Resour. Manage., 21, 873-882, 2007.

Gómez-Limón, J. A. and Riesgo, L.: Irrigation wáter pricing: differential impacts on irrigated farms, Agr. Econ., 31, 47-66, 2004

Greene, W. H.: Econometric Analysis, 5th ed. Pearson Education, New Jersey, 148-161, 2003.

Griliches, Z.: Research Expenditures, Education, and the Aggregate Agricultural Production Function, The American Economic Review, 54(6), 961-974, 1964. 
Hammersley, J. M. and Handscomb, D. C.: Monte Carlo Methods, Fletcher \& Sons Ltd, Norwich, Great Britain, Chapters 1 and 5, 1-9, 50-75, 1975.

Hayes, M.: Drought indexes, National Drought Mitigation Center, Nebraska, USA, http://drought.unl.edu/whatis/indices.htm, 2004.

Herranz-Loncán, A.: Agua y Desarrollo Económico en la Cuenca del Ebro (1926-2000), in: Gestión y Usos del Agua en la Cuenca del Ebro en el siglo XX, edited by: Pinilla Navarro, V., Prensas Universitarias de Zaragoza, 675-703, 2008.

Hussain, S. S. and Mudasser, M.: Prospects for wheat production under changing climate in mountain areas of Pakistan: An econometric analysis, Agr. Syst., 94, 494-501, 2007.

Iglesias, A., Garote, L., Flores, F., and Moneo, M.: Challenges to mange the risk of water scarcity and climate change in the Mediterranean, Water Resour. Manage., 21(5), 227-288, 2007.

Iglesias, A. and Quiroga, S.: Measuring the risk of climate variability to cereal production at five sites in Spain, Clim. Res., 34, 47-57, 2007.

Iglesias, A., Rosenzweig, C., and Pereira, D.: Agricultural impacts of climate change in Spain: developing tools for a spatial analysis, Global Environ. Change, 10, 69-80, 2000.

INE: Statistical Yearbook of Spain and Labour Force Survey (LFS), Years: 1976-2008, National Institute of Statistics, Madrid, Spain, http://www.INE.es, 2009.

Johnston, J. and Dinardo, J.: Métodos de Econometría, $1^{a}$ Edición, Vicens Vives, España, 2001.

Just, R. E. and Weninger, Q: Are crop yields normally distributed?, Am. J. Agr. Econ., 81(2), 287-304, 1999.

Keyantash, J. and Dracup, J. A.: The Quantification of Drought. An Evaluation of Drought Indices, B. Am. Meteorol. Soc., 83, 1167-1180, 8 Aug 2002.

Llop, M.: Economic impact of alternative water policy scenarios in the Spanish production system: An input-output analysis, Ecol. Econ., 68, 288-294, 2008.

Lobell, D. B. and Ortiz-Monasterio, J. I.: Regional importance of crop yield constraints: Linking simulation models and geostatistics to interpret spatial patterns, Ecol. Model., 196, 173-182, 2006.

Lobell, D. B., Ortiz-Monasterio, J. I., Asner, G. P., Matson, P. A., Naylor, R. L., and Falcon, W. P.: Analysis of wheat yield and climatic trends in Mexico, Field Crops Res., 94, 250-256, 2005.

Lobell, D. B., Ortiz-Monasterio, J. I., and Falcon, W. P.: Yield uncertainty at the field scale evaluated with multi-year satellite data, Agr. Syst., 92, 76-90, 2007.

MARM: Anuarios de Estadística Agroalimentaria, Years: 19762007, Spanish Ministry of Environment and Rural and Marine, Statistical Division, Madrid, 2007.

McKee, T. B., Doesken, N. J., and Kleist, J.: The relationship of drought frequency and duration to time scales, 8th Conference on Applied Climatology, Anaheim, CA, UISA Press, 36-66, 1993.
OECD: Sustainable Management of Water Resources in Agriculture, OECD, 2010.

Parry, M. A., Rosenzweig, C., Iglesias, A., Livermore, M., and Fischer, G.: Effects of climate change on global food production under SRES emissions and socio-economic scenarios, Global Environ. Change, 14, 53-67, 2004.

Quiroga, S. and Iglesias, A.: A comparison of the climate risks of cereal, citrus, grapevine and olive production in Spain, Agr. Syst., 101, 91-100, 2009.

Quiroga, S. and Iglesias, A.: A comparison of the climate marginal productivity on representative crop yields in Spain. Principios, Estudios de Economía Política., 16, 55-70, 2010.

Robert, C. P. and Casella, G.: Monte Carlo Statistical Methods (2nd edition), New York, Springer-Verlag, ISBN 0-387-212396, 2004.

Rubinstein, R. Y.: Simulation and the Montecarlo Method, John Wiley \& Sons, USA, Chapter 3, 81-96, 1981.

Schwarz, G.: Estimating the dimension of a model, Ann. Stat., 6, 461-464, 1978.

Smith, L.: Reforma y descentralización de servicios agrícolas: un marco de políticas, Colección de política agrícola y desarrollo económico de FAO, Roma, Chapter 11, http://www.fao.org/ docrep/005/y2006s/y2006s0f.htm\#TopOfPage, 2002.

Solow, R. M.: A Contribution to the Theory of Economic Growth, Q. J. Econ., 70, 65-94, 1956.

Solow, R. M.: The Economic of Resources or the Resources of Economics. The American Economic Review, 64 (May), 1-14, 1974

Steinmann, A., Hayes, M., and Cavalcanti, L.: Drought Indicators and Triggers, in: Drought and Water Crises, Science, edited by: Wilhite, D., Technology and Management Issues, CRC Press., 2005.

Stiglitz, J. E.: A Neoclassical Analysis of the Economics of Natural Resources, in: Scarcity and Growth Reconsidered, edited by: Smith, V. K., Baltimore, Johns Hopkins, 1979.

Stiglitz, J. E.: Reply, Georgescu-Roegen versus Solow/Stiglitz, Ecol. Econ., 22, 269-70, 1997.

Tsakiris, G., Loukas, A., Pangalou, D., Vangelis, H., Tigkas, D., Rossi, G., and Cancelliere, A.: Drought Characterization in Drought Management Guidelines Technical Annex", Cap. 7., 85-102, 2007.

Water Framework Directive (WFD): Directive 2000/60/EC UE Directive, European Commission, 23 October, http://ec.europa.eu/ environment/water/water-framework/index_en.html, 2000.

White, H.: A Heteroscedasticity-Consistent Covariance Matrix Estimator and a Direct Test for Heteroscedasticity, Econometrica, $48,817-838,1980$.

Wooldridge, J.: Introductory Econometrics: A modern approach, 2nd ed. Thomson USA, 2003. 